\title{
$\mathrm{Ti}_{3} \mathrm{Al}$ 単相中における相互拡散 ${ }^{\dagger}$
}

\author{
加藤雅彦*†† 笹野久興** 鈴 木敏 之* \\ *工学院大学大学院工学研究科機械工学專攻 \\ **金属材料技術研究所
}

J. Japan Inst. Metals, Vol. 63, No. 5 (1999), pp. 656-660

\section{Single-Phase Interdiffusion in Intermetallic Compound $\mathrm{Ti}_{3} \mathrm{Al}$}

\author{
Masahiko Kato*t†, Hisaoki Sasano** and Toshiyuki Suzuki*
}

*Department of Mechanical Engineering, Graduate School of Engineering, Kogakuin University, Tokyo 163-8677

**National Research Institute for Metals, Tsukuba 305-0047

\begin{abstract}
Interdiffusion in single-phase $\mathrm{Ti}_{3} \mathrm{Al}$ has been investigated using a vapor-solid diffusion couple in the temperature range between 1086 and $1345 \mathrm{~K}$. Aluminum was diffused by a chemical transportation technique in which aluminum chloride was used as the carrier gas. The results show that the interdiffusion coefficients at temperatures above $1209 \mathrm{~K}$ are almost the same at both sides of stoichiometry. However, the diffusion mode below 1132 $\mathrm{K}$ is completely different from that above $1209 \mathrm{~K}$. Although the diffusion layer is formed uniformly in the surface of the base metal above $1209 \mathrm{~K}$, the new crystal grains which are obviously different from the grains in the base metal are formed in the surface of the base metal below $1132 \mathrm{~K}$. As the result, aluminum diffuses along the newly formed crystal grain boundary. This means that the interdiffusion below $1132 \mathrm{~K}$ must be controlled by a grain boundary diffusion mechanism instead of the lattice diffusion above $1209 \mathrm{~K}$.
\end{abstract}

(Received October 16, 1998; In Final Form January 18, 1999)

\begin{abstract}
Keywords: intermetallic compound, interdiffusion, $T i_{3} A l$, vapor-solid diffusion couple, grain boundary diffusion
\end{abstract}

\section{I. 緒言}

広い組成領域をもつ金属間化合物では, $\mathrm{AgMg}^{(1)}$, $\mathrm{NiAl}^{(2)(3)}$ のように化学量論組成付近において拡散係数が低 くなる場合がある。著者らは NiAl 金属間化合物中にまい て, $1123 \mathrm{~K}$ 以下の低温では化学量諭組成を挟んだ広い領域 で相互拡散係数が異常に低くなることを報告した(4)。金属間 化合物に扣いては，特に化学量論組成近傍での組成のわずか な変動が機械的性質などの特性に大きな影響を及注すことが あり，拡散係数の正確な值を知ることは欠陮構造や相分離な ぞの微細構造に関する情報を得ることができ, また材料開発 などを行ら上で非常に重要でめる。

$\mathrm{Ti}_{3} \mathrm{Al}$ は高比強度耐熱材料と乙て注目されている $\mathrm{Ti}-\mathrm{Al}$ 系 金属間化合物の中でも, 現在実用域に達している材料であ る. $\mathrm{Ti}_{3} \mathrm{Al}$ は $\mathrm{D}_{19}$ 型結晶構造の金属間化合物であり，化学 量論組成より $\mathrm{Al}$ 過剰側に広い組成領域をもっている. 今ま でに, Ouchiら(5)による多相拡散実験, Sprengel ら ${ }^{(6)}$, Rüsing と Herzig ${ }^{(7)(8)}$ とよる単相拡散実験において $\mathrm{Ti}_{3} \mathrm{Al}$ 相 中の相互拡散係数が測定されている。しかし，多相拡散実験

† 1998年 9 月日本金属学会秋期大会炕拈いて一部発表

计工学院大学大学院生 (Graduate Student, Kogakuin University)
では相境界の移動をともならために，相境界付近の拉散係数 を正確に求めることは困難である。また Sprengel らの実験 では組成が 28 at\% A1 以上拈よび温度が $1171 \mathrm{~K}$ 以上， Rüsing と Herzig らの実験では組成が 26 at \% Al 以上拉よび 温度が $1170 \mathrm{~K}$ 以上の値しか報告されていない，本研究で は，1086〜1345 K の温度範囲で，化学量論組成を挟んで $\mathrm{Al}$ 不足側から $\mathrm{Al}$ 過剩側妾での組成領域の全域に亘る相互拡散 係数を求め, その組成依存性预よび温度依存性を明らかにす ることを目的とした。

\section{II. 実 験 方 法}

純度 $99.99 \%$ \%ルミニウムとJIS 1 種のスポンジチタン (純度 $99.5 \%$ 以上)を原料としてアルゴン雲囲気中でアーク溶 解し，組成が Ti-23 at\% Al 拈よび Ti-23.5 at\% $\mathrm{Al}$ の $70 \mathrm{~g}$ の ボタンインゴットを作製した。ボタンインゴットを $1273 \mathrm{~K}$ で $604.8 \mathrm{ks}$ 均質化焼鈍した後, $10 \mathrm{~mm} \times 10 \mathrm{~mm} \times 1 \mathrm{~mm} の$

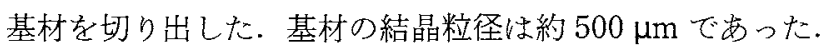

温度傾斜炉中に置かれた, 内径 $16 \mathrm{~mm}$, 長さ $1 \mathrm{~m}$ (内容積 約 $200 \mathrm{~cm}^{3}$ )のアルミナ製密閉容器内で, 塩化アルミニウム ガスを輸送媒体とした気体輸送法(9)(10)を用いて，表面が $\mathrm{Ti}_{3} \mathrm{Al}$ 相の高 $\mathrm{Al}$ 濃度組成となるような条件で, 基材表面か 
らアルミニウムを払散浸透させた。本実験で用いた気体輸送 法では，アルミニウムの活量の制御をアルミニウム源温度と 基材温度の制御によりできるので，容易に基材の表面組成を 制御することがでさる，基材はアルミニウム源温度より高温 側に数個並べて置いた。アルミニウム源には純アルミニウム 数 $\mathrm{g}$ と, 添加剤として塩化アンモニウム $60 \mathrm{mg}$ 置いた。 アルミニウム源の加熱温度は $1069 \mathrm{~K}$ から約 $50 \mathrm{~K}$ 扣きに $1337 \mathrm{~K}$ でとし，アルミニウムの桩散浸透深さが $20 \mu \mathrm{m}$ 以 上となるよらに 930〜 $2700 \mathrm{ks}$ 加熱した。拡散処理後の試料 断面をJIS\#1200孚でェメリ一紙研磨により研磨した後， コロイダルシリカによるバフ研磨によって鏡面仕上げした。

試料断面のアルミニウムおよびチタンの濃度分布は，島津 製作所 EPMA-8705 型電子線プローブマイクロアナライザ (EPMA)により测定した. Ti-Al二元系のアルミニウムのX 線強度に対する $\mathrm{Al}$ 濃度の検量線を，23 at\% $\mathrm{Al}$ 扣よび 24 36 at\% $\%$ l の範囲で組成を 2 at\% \%きに变えた合金と，純子 タン板表面に TiAl 相が形成される条件でアルミニウムを拡 散浸透させた場合に形成される TiAl 相まよび $\mathrm{Ti}_{3} \mathrm{Al}$ 相の $\mathrm{X}$ 線強度から求めた。組織観察はフッ酸と硝酸と水が $1: 3$ : 200 溶液で腐食し，走查電子顕微鏡(SEM)により行った。 相互拡散係数は Boltzmann-Matano の方法により求めた。
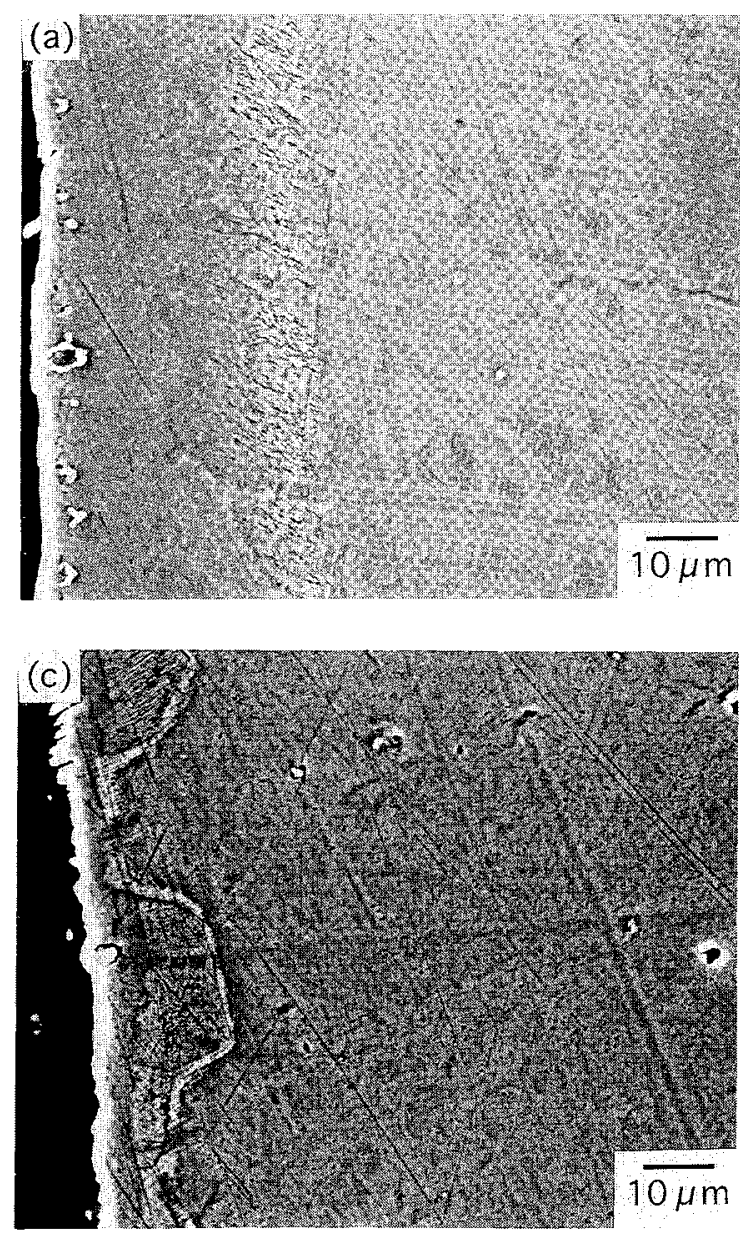

\section{III. 実験結果および考察}

\section{1. 拡散層の様相}

SEM により表面付近の断面を観察した結果，処理温度が $1132 \mathrm{~K}$ 以下と $1209 \mathrm{~K}$ 以上で拡散層の成長の仕方が異なる ことがわかった。代表例として $1258 \mathrm{~K}$ の場合と $1086 \mathrm{~K}$ の 場合のSEM 像を Fig. 1 亿示す。母材の結晶粒界が存在し ない部分では，Fig.1(a)に示すよらに，1258Kの試料では 母材の結晶粒内と同一の結晶粒内に表面から内部に一定厚さ の拡散層が形成されているのが観察される。これに対して $1086 \mathrm{~K}$ の試料では Fig. 1(c)に示すよらに, 粒径約 $500 \mu \mathrm{m}$

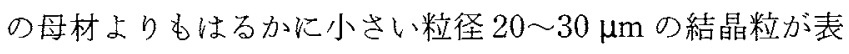
面に局所的に形成されている，母材の結晶粒界が表面るで存 在する部分では， $1258 \mathrm{~K}$ の試料では Fig. 1(b)に示すよ5 に, 粒界以外の部分と比較して粒界部分飞特暴な現象は観察 されないのに対して，1086 K の試料ではFig. 1(d)に示すよ らに，粒界に沿って結晶粒が成長し深くまで抆散層が形成さ れている.これらのことから，1209 $\mathrm{K}$ 以上の高温と $1132 \mathrm{~K}$ 以下の低温では拡散機構が異なるものと考えられる。るた， $1209 \mathrm{~K}$ 以上の高温では粒界拡散の影響は汪とんど見られな
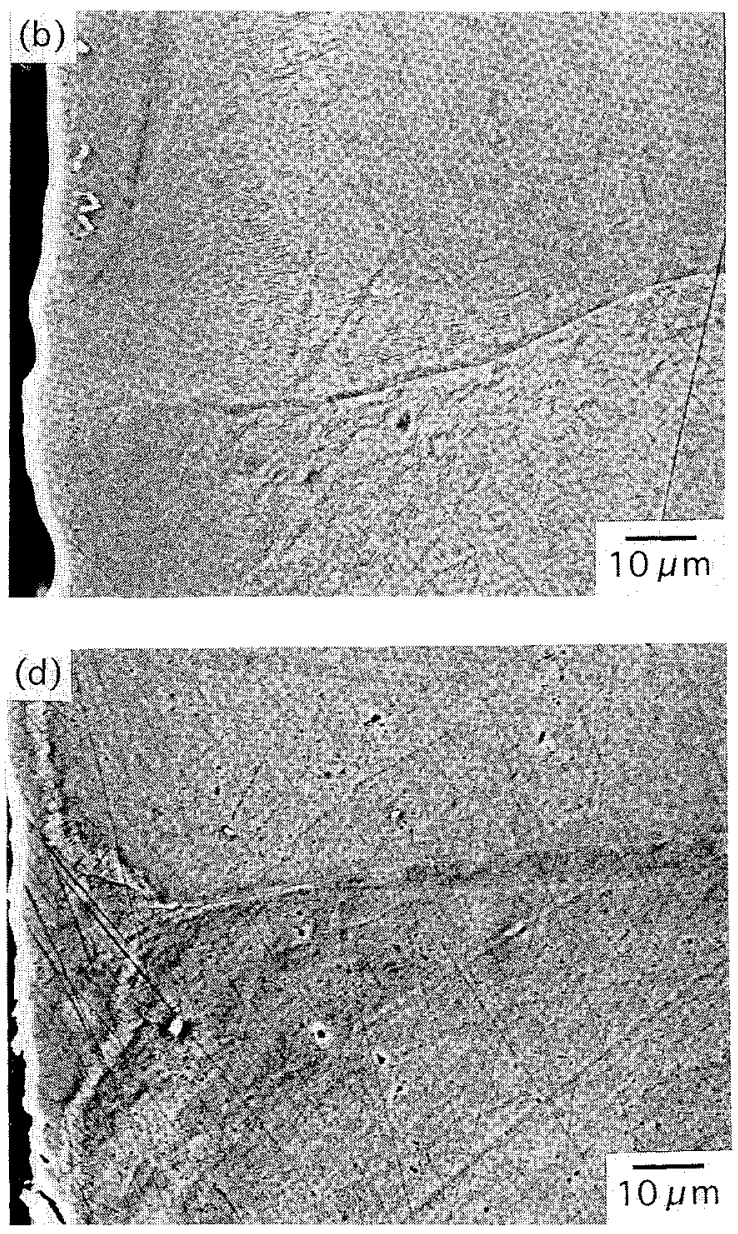

Fig. 1 SEM images of $\mathrm{Ti}_{3} \mathrm{Al}$ after the diffusion treatment (a) (b) at $1258 \mathrm{~K}$ for $1615 \mathrm{ks}$ and (c) (d) at $1086 \mathrm{~K}$ for $2500 \mathrm{ks}$. 
いのに対して，1132 K 以下の盜度では粒界拡散が体拡散に 比べて大きくなることがわからた。

\section{2. 拡散層断面の面分析}

EPMAにより試料断面の表面付近のアルミニウムの濃度 分布を約 $100 \mu \mathrm{m} \times 100 \mu \mathrm{m} \sim 200 \mu \mathrm{m} \times 200 \mu \mathrm{m}$ の領域で測定 した。濃度分布図の例として $1295 \mathrm{~K}$ と $1086 \mathrm{~K}$ の場合を Fig. 2 に示す。赤色の部分は $\mathrm{Al}$ 濃度が高く, 赤, 橙, 黄, 緑, 青色の順に $\mathrm{Al}$ 濃度は低くなっている. 図中に示した濃 度プロファイルは，約 $10 \mu \mathrm{m}$ の間隔の 2 本の平行線の間の 濃度の平均である。Fig. 2 (b)の $1086 \mathrm{~K}$ の場合は拡散層の厚 さが位置によって異なるため，層の薄い部分 (1) と厚い部分 (2)の2本の濃度プロファイルを示してある。すなわち,
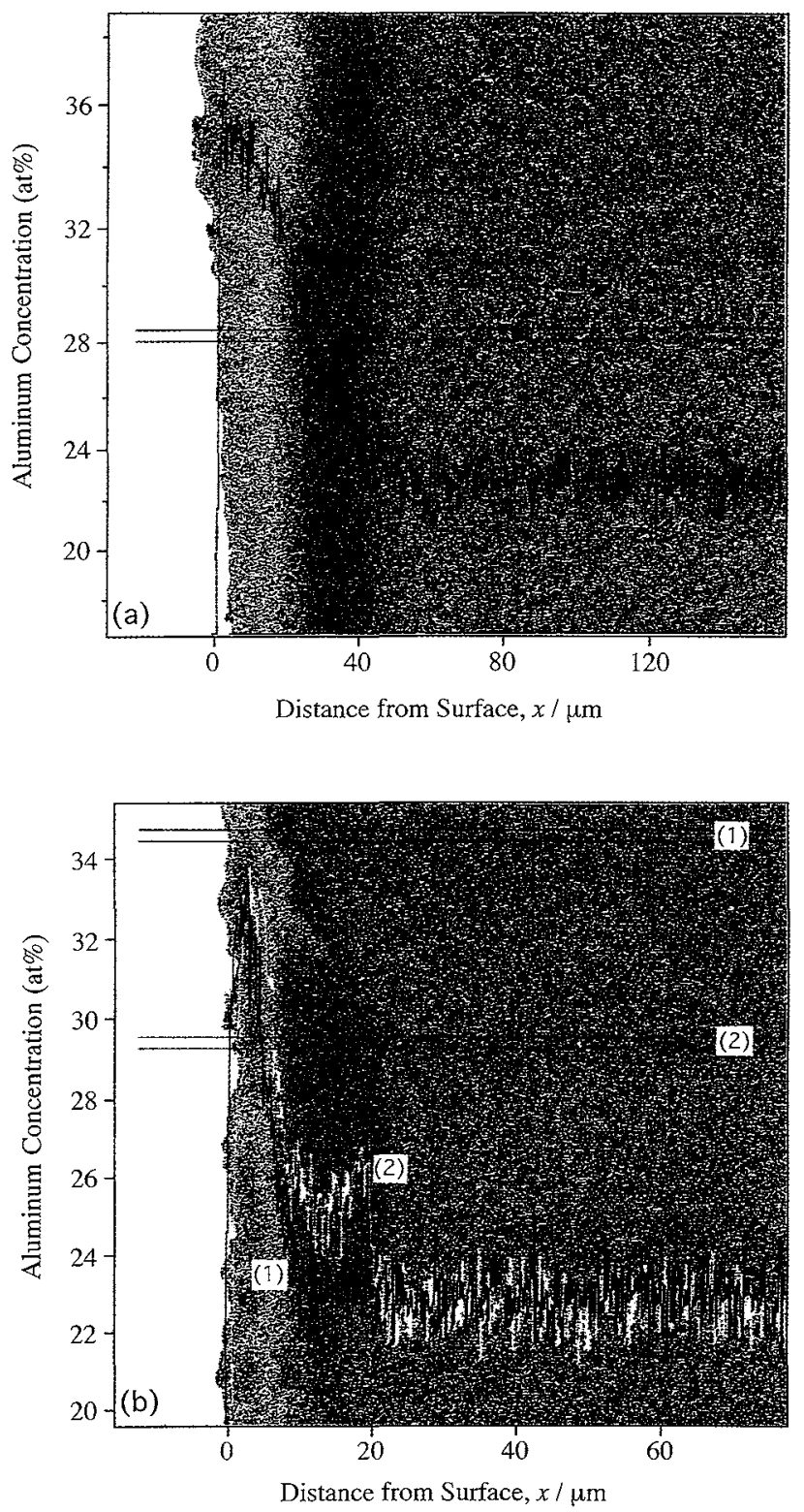

Fig. 2 Concentration distribution maps and concentration profiles of $\mathrm{Al}$ in $\mathrm{Ti}_{3} \mathrm{Al}$ after the diffusion treatment (a) at 1295 $\mathrm{K}$ for $930 \mathrm{ks}$ and $(\mathrm{b})$ at $1086 \mathrm{~K}$ for $2500 \mathrm{ks}$.
Fig. 2(b)の (2)の部分は, Fig. 1(c)における表面に形成され た結晶粒が深くまで成長している部分に対応し，(1)の部分 は深く委で拡散層が形成されていない部分に対応している.

1295 K の場合では，Fig. 2(a)に示すように，Al 濃度は表 面から内部に向かってなだらかに減少して扣り，表面から同 じ深さの点では位置の違いによる $\mathrm{Al}$ 濃度の差はほとんどな いしかし，1086 K の場合では，Fig. 2(b)のよ5に位置に より $\mathrm{Al}$ 濃度が異なっている。拡散層が薄い部分 (1)では, $\mathrm{Al}$ 濃度は表面から母材の組成である 23 at\% $\mathrm{Al}$ まで徐々に 減少するプロフォイルを示している，搪散層が厚い部分 (2) について，結晶粒の内部を横切って深さ方向に濃度プロフっ イルをとると，Al 濃度は表面から $5 \mu \mathrm{m}$ で徐々と 7 at \% 減 少しているが，粒の中心部に近づくにつれて減少率は 0.2

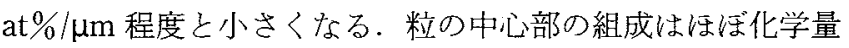
論組成である。粒の中心部を越えると $\mathrm{Al}$ 濃度は母材との粒 界をで緩やかに増加し，母材との粒界で極大值をとるが，粒 界を越えると急激に 3 at $\%$ も減少を示し母材の組成に到達

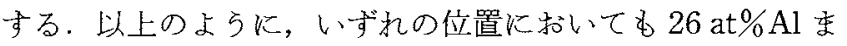
では表面から徐々に減少する濃度プロファイルを示すが，化 学量論組成近傍から低 $\mathrm{Al}$ 濃度側の 26〜23 at\% $\mathrm{Al}$ では，位 置によってAl濃度の変化が異なることが明らかになった。 また，新たに形成された結晶粒の粒界付近では， $\mathrm{Al}$ 濃度が 結晶粒内部よりも高くなることが Fig. 2(b)で観察される.

Fig. 1(c)の組織観察の結果乱よび Fig. 2(b)の試料断面の $\mathrm{Al}$ 濃度の面分析の結果から, $1132 \mathrm{~K}$ 以下の低温では, 母材 表面に母材と異なる方位の新たな結晶粒が形成され，新たな 結晶粒と母材の粒界扣よび新たな結晶粒どうしの粒界に沿っ て拡散が著しいと推測される。 また, 表面と直角方向の粒界 に沿った拡散が進むにつれて新たな結晶粒も成長し，表面と 平行な粒界も深さ方向へ移動していくことによって, 試料の 深さ方向にアルミニウムが深く浸透すると推定される.

このよらな低温での様相,すなわち拡散にともなった結晶 粒界の移動はHillertとPurdy(11)によって示されたdiffusion-induced grain boundary motion (DIGM)の様相と似て いる. DIGM に関する実験結果は Bulluffi と Cahnによって まとめられており，DIGM は体拡散より粒界搪散が顕著に 現れる低温で起こるとされている(12)。このことは，本実験 での結晶粒の成長をともなら搪散が，粒界拡散の影響が著し い低温でのみ起こる事実と類似している.

\section{3. 相互拡散係数の組成依存性および温度依存性}

種々の条件に括ける濃度プロファイルの例を Fig. 3 に示 す。位置によって拡散層の深さが異なる $1132 \mathrm{~K}$ および $1086 \mathrm{~K}$ の場合では，拡散層の薄い部分の濃度プロファイル を示してある。これら濃度プロフォイルは 1209 1345 K で は鿁差関数式に注湾フィットした。このことから，1209〜 $1345 \mathrm{~K}$ では相互桩散係数の組成依存性は注とんどないと推 定される。

$1132 \mathrm{~K}$ 以下の低温においては，結晶粒が深くまで成長す 
る領域の組成を調べるために，表面組成を変化させた実験を 行った，結晶粒が深くまで成長した場所の濃度プロファイル をFig. 4 に示す。いずれの場合も26 at\% Al 以上では，Al 濃度は勾配は大きいが表面から滑らかル減少しているのに対 して, 26 at\% $\mathrm{Al}$ 以下では，特に化学量論組成付近で $\mathrm{A} 1$ 濃 度の変化が不規則になっている。このことは粒界拡散の効果 が化学量論組成付近の組成に扣いて著しく大きくなることを 示している、純チタンの表面組成を変化させる実験に执い て，1080 K 付近では 25 28 at\%Al 拈よび 32 34 at\%Al の組成範团の表面組成を得ることは困難であった ${ }^{(9)}$ 。本実験

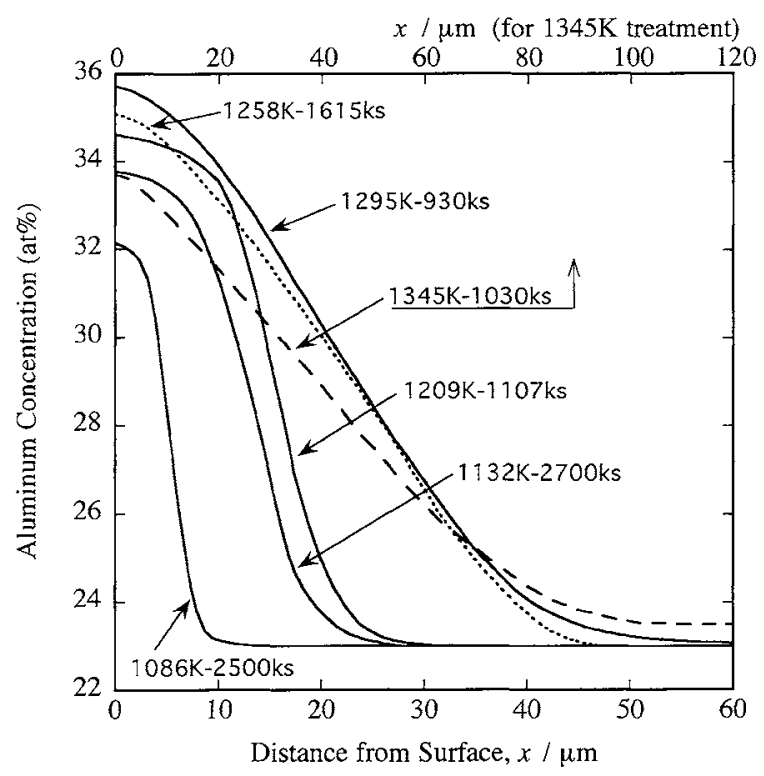

Fig. 3 Concentration profiles of $\mathrm{Al}$ in $\mathrm{Ti}_{3} \mathrm{Al}$ after the diffusion treatment under various conditions.

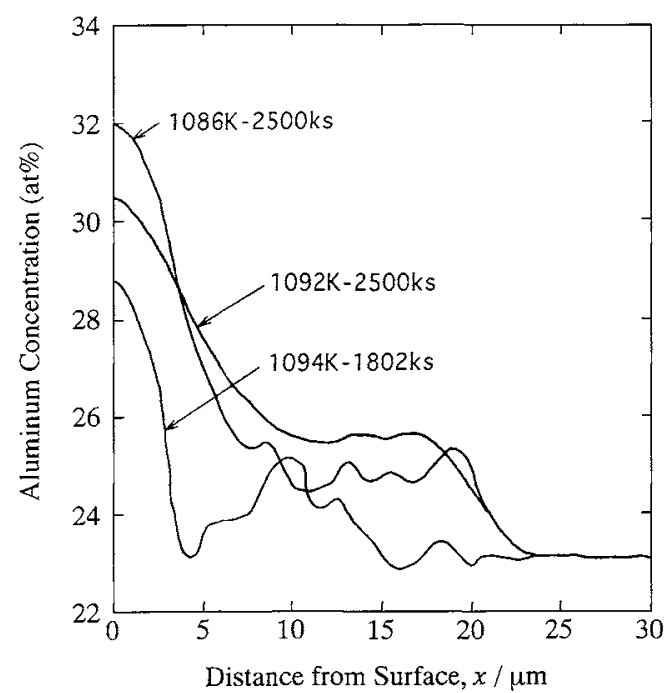

Fig. 4 Concentration profiles obtained from thick part in the diffusion layer after the diffusion treatment at low temperatures. The surface concentration was controlled by changing the temperature difference between aluminum source and the specimen.
そ和いても $1080 \mathrm{~K}$ 前後の温度において同じ組成範囲の表面 組成は得られなかった。これらの組成範囲では，アルミニウ ムの活量が汪とんど組成に依存せず一定であり，活量を反映 した化学ポテンシャルの勾配は著しく小さいと考光られる. すなわわこれらの組成範困での相互拡散係数は著しく小さく なるものと推測される。しかし，Fig.4の漂度プロファイル では，化学量論組成付近に和いて深くまで拡散層が成長して いるために拡散係数は大さいように見光，25〜28 at\%Alの 組成範囲で拡散係数が小さくなるといら推測と矛盾している ように思われるが，実際はFig. 2 の濃度分布図のように， アルミニウムは粒界に沿って結晶粒を回り込んで拡散して数 り, 粒界昖散の効果が化学量論組成付近で著しく大きいと考 えれば説明できる。これらのことから，化学量論組成付近で は格子应散だけで考えれば桩散係数はより小さい值を示すと 考兄られるが，実際は粒界拡散の効果が現れるために拡散係 数はより大きい值を示すと考兄ら机る。なぜ粒界拡散が化学 量論組成付近で著しくなるかについては, 現在のところ不明 である. 32 at\% $\mathrm{Al}$ 以上の組成については，表面に TiAl 相 が形成される条件で実験を行い濃度分布を測定した結果， $\mathrm{TiAl}$ 相と $\mathrm{Ti}_{3} \mathrm{Al}$ 相の境界付近の $\mathrm{Ti}_{3} \mathrm{Al}$ 相中の濃度勾配は著 しく大きいことがわかった。このことから，32 at\% $\%$ Al上 の高 $\mathrm{Al}$ 濃度組成では拉散係数は小さい值を示すと考克られる.

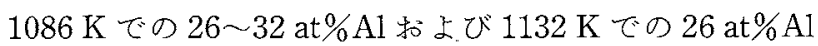
以上の組成については，組織観察や濃度分布の湘定に和乱る 結果から高温の場合と拡散機構が異なると考光られるので, 組成依存性があるかどらかは確かではない。

Fig. 3 飞示した濃度プロフォイルから，BoltzmannMatanoの方法により相互拡散係数 $\tilde{D}$ を求めた結果を Fig. 5 に示す。縦軸を $\log \tilde{D}$ でとったこの図では，1209〜1345

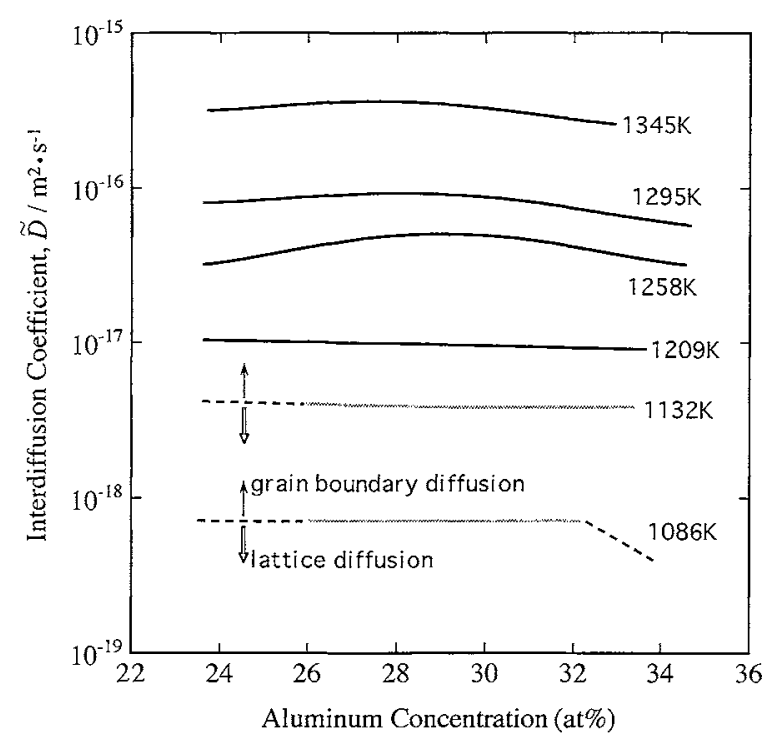

Fig. 5 Composition dependence of $\tilde{D}$ in $\mathrm{Ti}_{3} \mathrm{~A} 1$. At $1132 \mathrm{~K}$ and $1086 \mathrm{~K}$, the values shown are obtained from thin part in the diffusion layer. 


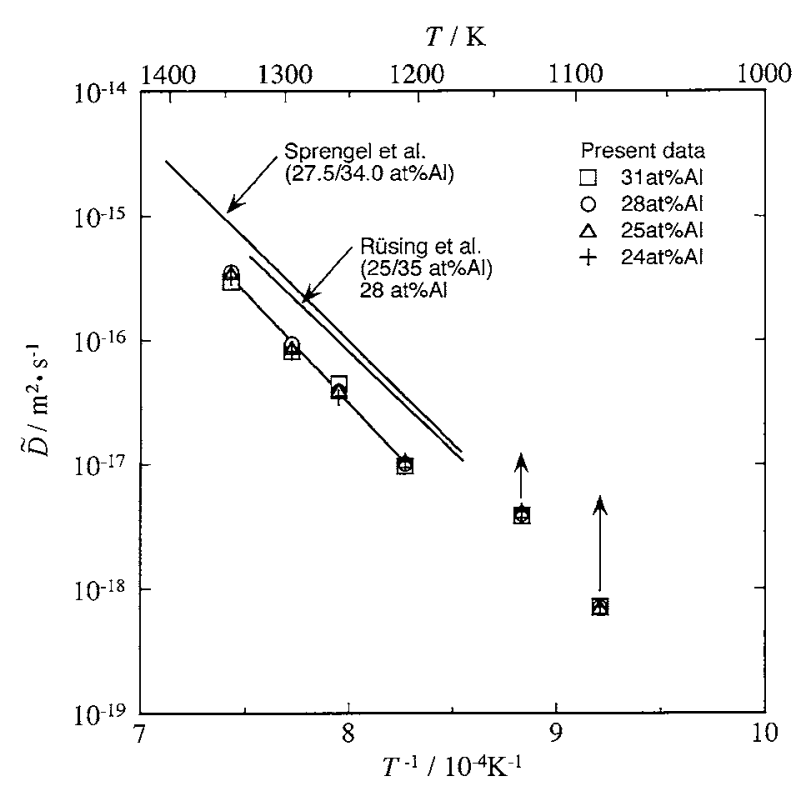

Fig. 6 Temperature dependence of $\tilde{D}$ in $\mathrm{Ti}_{3} \mathrm{~A} 1$.

$\mathrm{K}$ では広い組成範囲で添汸一定の值を示し，特に化学量論 組成前後に括いて子值は変化しないことが明らかになった。

$1132 \mathrm{~K}$ 以下については，拡散層の薄い部分でとった濃度 プロファイルから $\tilde{D} を$ 求めたため薄い線で示した. $1086 \mathrm{~K}$ の 32 at \% $\mathrm{Al}$ 以上を点線で示したのは，TiAl 相を表面に形 成させた反応拡散実験の結果，32 at \% Al 以上では濃度勾配 が大さいために拆散係数が小さくなると考它られるためであ る. $1132 \mathrm{~K}$ および $1086 \mathrm{~K} の 26$ at\% Al 以下については，粒

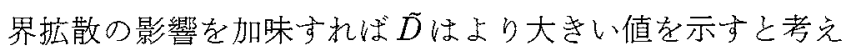
られるために点線で示した。

Fig. 6 K相互拡散係数のアレニウス・プロットを示す. ここでは組成24, 25, 28拉よ゙゙ 31 at\% Alの值をプロットし てある. $1209 \mathrm{~K}$ 以上では，いずれの組成に执いても同一直 線上そプロットされることから，活性化エネルギーに組成依 存性はないと考えられる。Fig. 6 に示したSprengel ら (6) 叔 よび Rüsing と Herzig ${ }^{(8)}$ にって求められた值と比較する と, 本実験の相互拡散係数の值は両者の值の約 $1 / 2$ 程度であ るが，この勾配から求まる活性化エネルギー $\tilde{Q}$ 小 $340 \mathrm{~kJ}$. $\mathrm{mol}^{-1}$ であり, Sprengel らとよって求められた值 $312 \pm 6$ $\mathrm{kJ} \cdot \mathrm{mol}^{-1}$ および Rüsing と Herzigによって求められた值約 $310 \mathrm{~kJ} \cdot \mathrm{mol}^{-1}$ と比較的良く一致している.

$1132 \mathrm{~K}$ 以下の場合は, 拡散層の薄い部分でとった濃度プ ロファイルから求めた相互拡散係数の值を示しているが，こ れらの值でさえも $1209 \mathrm{~K}$ 以上の直線の徙長線上よりも上万 にプロットされている。このことは低温では，拡散層の薄い 部分でさえも高温の場合と拡散機構が異なり，粒界拡散の影 響がわずかに現れているものと考光られる。特に 26 at $\% \mathrm{Al}$ 以下の粒界拡散が著しい部分では，相互拡散係数の值はさら に上方にプロットされると考えられるため知印で示した。 $1132 \mathrm{~K}$ 以下の低温では, 拡散層の厚さが位置によって異な
るために，粒界拉散係数そのものは求められなく，粒界拡散 の活性化エネルギーも求めることはできなかったが，低温で は一般に粒界に括ける拡散係数は大きく, 粒界拡散の活性化 エネルギーは小さくなることがわかっている(13)。したがっ て，本実験に扣いて結晶粒が表面から深く成長している 26 at\%Al 以下の部分，すなわち粒界拡散の影響が大さい部分 では，相互拡散係数は大さく，活性化ェネルギーは体拡散に 対応した高温に打ける值よりも小さい值を示すと推定される。

\section{N. 結 論}

気体輸送法による気体-固体拡散対を用いて，1086〜1345 $\mathrm{K}$ の温度範囲で $\mathrm{T} \mathrm{i}_{3} \mathrm{Al}$ 単相中の拡散実験を行い，次のよう な結果を得た。

(1) $1209 \mathrm{~K}$ 以上と $1132 \mathrm{~K}$ 以下では拡散の機構が異なり， $1209 \mathrm{~K}$ 以上で贯材の結晶粒内にアルミニウムが抎散する のに対し，1132 K 以下の低温では，母材と異なる新たな結 晶粒が母材表面に形成され，この結晶粒と母材との粒界执よ び新たに形成された結晶粒どうしの粒界に沿ってアルミニウ ムが拡散することがわかった。 $1132 \mathrm{~K}$ 以下では，新たに形 成された結晶粒の成長は粒界拡散に支配され，DIGMに似 た様相を呈した。

(2) 1209〜1345 K では，化学量論組成を挟んだほぼ組成 領域全域に亘って相互拡散係数にほとえど組成依存性はなか った。

（3） 1209 1345 K では活性化エネルギーに組成依存性は

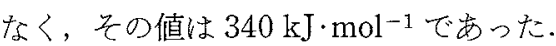

EPMAの分析に関して有益なアドバイスを戴いた，金属 材料技術研究所の本間一廣氏に深く感謝致します。

\section{文献}

(1) H. A. Domian and H. I. Aaronson: Trans. AIME, 230(1964), 44.

(2) G. F. Hancock and B. R. McDonnell: Phys. Stat. Sol., 4A (1971), 143.

(3) S. Shankar and L. L. Seigle: Met. Trans., 9A(1978), 1467.

（4）加藤雅彦，笹野久興，本間一廣，鈴木敏之：日本金属学会誌 62(1998), 761 .

(5) K. Ouchi, Y. Iijima and K. Hirano: Proc. of 4th Int. Conf. on Titanium, Kyoto, Ed. by H. Kimura and O. Izumi, AIME, New York, (1980), 559.

(6) W. Sprengel, H. Nakajima and H. Oikawa: Mater. Sci. Eng., A213(1996), 45.

(7) J. Rüsing and Chr. Herzig: Scr. Metall. Mater., 33(1995), 561.

(8) J. Rüsing and Chr. Herzig: Intermetallics, 4(1996), 647.

(9) M. Kato, H. Sasano and T. Suzuki: Mater. Sci. Eng., A243 (1998), 212.

(10) M. Kato, H. Sasano and T. Suzuki: Proceedings of 11th Congress of the International Federation for Heat Treatment and Surface Engineering, Florene, 2(1998), 53.

(11) M. Hillert and G. R. Purdy: Acta Metall., 26(1978), 333.

(12) R. W. Balluffi and J. W. Cahn: Acta Metall., 29(1981), 493.

(13) P. G. Shewmon: Diffusion in Solids, McGraw-Hill, (1963), 171. 